\title{
Pregnancy rates and luteal phase characteristics of bovine embryo recipients treated with flunixin meglumine
}

[Taxas de prenhez e características da fase lútea de receptoras de embriões tratadas com flunixina meglumina em bovinos]

\author{
R.C. Cardoso $^{1}$, V.M. Codognoto ${ }^{1 *}$, P.F. Lainetti $^{1}$, P.H. Yamada ${ }^{1}$, G. Rizzoto ${ }^{2}$, L.C. Salgado ${ }^{1}$, \\ M.S. Araújo ${ }^{1}$, A.F. Vieira ${ }^{1}$, N.F.S. Marques ${ }^{1}$, E. Oba $^{1}$
}

${ }^{1}$ Faculdade de Medicina Veterinária e Zootecnia - Universidade Estadual Paulista "Júlio de Mesquita Filho"- FMVZ-UNESP- Botucatu, SP

${ }^{2}$ Faculty of Veterinary Medicine - University of Calgary - Calgary - AB, Canada

\begin{abstract}
The aim of this study was to evaluate the effects of flunixin meglumine administration on pregnancy rates and luteal phase characteristics in bovine embryo recipients at the moment of embryo transfer. In experiment 1 , in vitro produced embryos were transferred to 184 females divided as control and treated group (recipients treated with $1.1 \mathrm{mg} / \mathrm{kg}$ flunixin meglumine). In experiment 2,22 females were divided as control group; group 2 (animals submitted to a reproductive tract manipulation similar to an embryo transfer on the 7th day after estrous); and group 3 (females submitted to a manipulation and treatment with $1.1 \mathrm{mg} / \mathrm{kg}$ flunixin meglumine). In experiment 1 no difference was observed between control and treated groups $(40.2 \%$ and $44.6 \%$, respectively) for pregnancy rates. In experiment 2 no difference was observed on the length of luteal phase between groups, however, animals in group 2 presented lower plasma progesterone concentrations than the control group and group 3. Therefore, we concluded that although the administration of flunixin meglumine at the moment of embryo transfer inhibited the reduction plasma progesterone concentrations, it was not effective in increasing pregnancy rates of bovine recipients.
\end{abstract}

Keywords: Bos taurus, flunixin meglumine, corpus luteum, progesterone

\section{RESUMO}

O objetivo deste estudo foi avaliar os efeitos da administração de flunixina meglumina sobre as taxas de prenhez e características da fase lútea da receptora no momento da transferência de embriões em bovinos. No experimento 1, embriões produzidos in vitro foram transferidos para 184 fêmeas, divididas em grupos controle e tratado (tratados com $1,1 \mathrm{mg} / \mathrm{kg}$ de flunixina meglumina). No experimento 2, 22 fêmeas foram divididas em grupo controle $(n=7)$; grupo $2(n=8$; animais submetidos à manipulação do trato reprodutivo semelhante à transferência de embriões no sétimo dia pós-cio); e grupo 3 (n=7; fêmeas submetidas à manipulação e ao tratamento com $1,1 \mathrm{mg} / \mathrm{kg}$ de flunixina meglumina). No experimento 1 , não foi observada diferença nos grupos controle e tratado $(40,2 \%$ e 44,6\%, respectivamente) para as taxas de prenhez. No experimento 2, não houve diferença na extensão da fase lútea entre os grupos, entretanto os animais do grupo 2 apresentaram concentrações plasmáticas de progesterona mais baixas que o grupo controle e o grupo 3. Portanto, conclui-se que a administração de flunixina meglumina no momento da transferência de embriões inibiu a redução das concentrações plasmáticas de progesterona, no entanto não foi eficaz para aumentar as taxas de prenhez de receptoras em bovinos.

Palavras-chave: Bos taurus, flunixina meglumina, corpo lúteo, progesterona

Recebido em 22 de maio de 2019

Aceito em 2 de dezembro de 2019

*Autor para correspondência (corresponding author)

E-mail: viviane.codognoto@gmail.com 


\section{INTRODUCTION}

The genetic improvement of cattle herds is certainly the main mean by which productive efficiency and profitability of breeding systems can be improved. Among several genetic improvement techniques, embryo transfer and in vitro embryo production can be highlighted as tools improve the useof genetic material from cows (Dziuk; Bellows, 1983).

Despite the increase in numbers of bovine embryos transferred during the last years, the establishment of pregnancy in embryo recipients still presents high variability, which is well below the expected in most cases. This wide variation observed in pregnancy rates may be a result of several factors such as embryonic, maternal, environmental or even a combination of all (Young et al., 1998).

Furthermore, it was identified that manipulation of the recipient's reproductive tract at the time of embryo transfer results in the release of prostaglandin F2 $\alpha$ (PGF2 $\alpha$ ) by the endometrium (Schallenberger et al., 1989; Wann and Randel, 1990; Scenna et al., 2005).This increase in PGF2 $\alpha$ release by the endometrium may compromise the pregnancy rate through different pathways, such as detrimental action on embryo development or, for example, through impairment of luteal function of these recipients, which may indirectly affect embryo development (Wiltbank et al., 1989; Schrick et al., 2003; Hockett et al., 2004).

Aiming to increase the pregnancy rate in recipient cows, one can theorize that inhibition of prostaglandin synthesis would support the establishment of pregnancy, either by inhibition of prostaglandin direct adverse effects on embryonic development, or corpus luteum (CL) functionality. An interesting study (Elli et al., 2001) administered ibuprofen lysinate (a nonsteroidal anti-inflammatory drug that inhibits cyclooxygenase- 2 enzyme activity) one hour before embryo transfer and had higher pregnancy rates in the treated group compared to control ( $82 \%$ vs. $56 \%$ ), a fact also proven through the use of $5 \mathrm{mg} / \mathrm{kg}$ ibuprofen (IM) (Narváez et al., 2010). Furthermore, another study (Pugh et al., 2004) treated cows with aspirin, another cyclooxygenase- 2 inhibitor, and achieved a significant $18 \%$ increase in pregnancy rate compared to control cows. Lastly, the utilization of flunixin meglumine (FM) immediately after transfer, in recipients with and without cervical transposition, obtained pregnancy rates of $61.4 \%$ and $50 \%$, respectively, concluding that FM administration was able to increase pregnancy rates in cows presenting cervical transposition (Ribeiro Filho et al., 2011). However, more studies are required to better understand this interaction.

Therefore, the objective of the present study was to evaluate the influence of FM, an inhibitor of prostaglandin synthesis, on the pregnancy rate of bovine recipients of in vitro produced embryos, and its impact plasma progesterone concentrations $\left(\mathrm{P}_{4}\right)$ and luteal phase duration in the receptors.

\section{MATERIAL AND METHODS}

All experiments were performed under protocols approved by the Animal Care and Use Committee, number 48/2007 - CEEA.

Experiment 1: Effect of flunixin meglumine on bovine embryo recipient's pregnancy rate. For this study, adult primiparous and multiparous $(n=184)$ crossbred bovine embryo recipients were used, with a body score condition equal to or greater than 3 (0 to 5 scale), showing cyclic ovarian activity and period after delivery of more than 60 days. A hundred and eighty-four in vitro embryos produced by Bioembryo ${ }^{\circledR}$ laboratory were used. The oocytes used were originated from follicular aspirations of Zebu (Bos indicus) matrices (Nelore and Guzerá). The semen used for IVFs came from a single zebu bull (Nellore and Guzerá), and the semen used came from the same breed of bull that originated the oocyte.

Only grade 1 quality embryos at developmental stage of initial blastocyst (BI; $n=40)$, blastocyst $(\mathrm{BL} ; \mathrm{n}=68)$ and expanded blastocyst $(\mathrm{BX} ; \mathrm{n}=$ 76) were used. The synchronization recipients were achieved with $500 \mu \mathrm{g}$ IM application of cloprostenol (Ciosin ${ }^{\circledR}, \quad$ Schering-Plow, São Paulo, SP, Brazil). Between 2 and 5 days after application the animals were observed twice daily for heat detection.

The recipients were used between the 6th and 9th day after heat observation. On the day of the embryo transfer, the recipients were selected through rectal palpation and ultrasonography 
examination of the reproductive tract. Recipients that presented corpus luteum, adequate uterine tonus and diameter corresponding to luteal phase of estrous cycle were selected to receive embryos. All transfers were classified according to procedure difficulty, being determined as score 1 the procedures that cervix crossing was not difficult and embryo transfer gun was positioned in the final third of uterine horn. In score 2 there was a moderate difficulty to perform the procedure and in 3 there was a great difficulty.

After the transfers, the recipients were divided into two groups: group 1 (control) and group 2 (experimental), with a randomized division of embryos between two groups so that both received the same number of $\mathrm{BI}, \mathrm{BL}$ and $\mathrm{BX}$. The animals in group 1 were released immediately after the procedure and the animals in group 2 received $1.1 \mathrm{mg} / \mathrm{kg}$ IM application of FM (Flunixin Injectable ${ }^{\circledR}$ Chemitec AgroVeterinária São Paulo, SP, Brazil) soon after the transfer.

Pregnancy diagnosis was performed through transrectal ultrasound examinations at 30 and 60 days of gestation using Esaote $®$ ultrasound device (Pie Medical Equipment BV, Maastricht, Netherlands), Aquila ProVet model, with a bifrequential transducer (6-8 MHz). Data on pregnancy rates were statistically analyzed using Chi-square test at a 5\% level of significance ( $\mathrm{p}$ $<0.05)$. For that, the FREQ procedure of SAS System for Windows ${ }^{\circledR}$ program (2001) was used.

Experiment 2: Effect of flunixin on luteal phase characteristics of bovine embryo recipients. For the second experiment, adult primiparous and multiparous Nelore cows $(n=33)$ with body score condition equal to or greater than 3 (0 to 5 scale) and showing cyclic ovarian activity and postpartum period of more than 90 days were used. The animals were synchronized by two applications of $500 \mu \mathrm{g}$ sodium cloprostenol IM (Sincrocio®, Ouro Fino Saúde Animal, Ribeirão Preto, São Paulo, Brazil), with an 11 day interval. Between 2 and 5 days after the second application the animals were observed twice day for heat detection.

On the seventh day (D7) after heat detection, ultrasound evaluation of the reproductive tract was performed on 25 females that demonstrated estrus to determine corpus luteum characteristics and also for uterine evaluation. At the same moment, blood sample was collected for subsequent $\mathrm{P}_{4}$ plasma concentration evaluation. At this stage, one animal was discarded from the experiment because it had liquid contents in the uterine lumen, one female was discarded for not having a clear image of one CL during ultrasonography examination, and another animal was later discarded because it had a $\mathrm{P}_{4}$ plasma concentration below $1 \mathrm{ng} / \mathrm{ml}$ on manipulation day (D7).

The remaining 22 animals were randomly divided into groups: group 1 (control, $\mathrm{n}=7$ ), group 2 (manipulation, $\mathrm{n}=8$ ) and group 3 (manipulation and FM application, $\mathrm{n}=7$ ). Group 1 did not undergo any type of reproductive tract manipulation besides ovaries and uterus submitted to ultrasound examination, furthermore, they did not receive any drugs during D7 or later during the experiment. Group 1 animals were submitted to sonographic examinations and hormonal levels between D7 and luteal phase end (D7, D11, D13, D14, D15, D16, D17, D18, D19 and D20) for $\mathrm{P}_{4}$ plasma concentration determination and $\mathrm{CL}$ functional duration.

The group 2 females were submitted to reproductive tract manipulation in $\mathrm{D} 7$, similar to embryo anovulation, after ultrasonography evaluation and blood collection. As in experiment 1 , the manipulations were classified with difficulty score of 1 to 3 . The animals in group 2 underwent ultrasound examinations and blood samples between D7 and the end of the luteal phase, similarly to the described for group 1 .

The group 3 females were submitted to reproductive tract manipulation in D7 soon after ultrasonographic evaluation and blood collection, in the same way as in group 2 animals. However, at the end of manipulation the animals received $1.1 \mathrm{mg} / \mathrm{kg}$ FM (Flunixin Injectable ${ }^{\circledR}$, Chemitec Agro-Veterinary, São Paulo, SP, Brazil) intramuscularly. Similar to the previously described, the animals underwent ultrasonographic examinations and blood sampling between D7 and the end of luteal phase to determine $\mathrm{P}_{4}$ plasma concentrations and corpus luteum functional duration.

Transrectal ultrasound examinations were performed using Aloka ${ }^{\circledR}$ ultrasound device 
(Aloka Co. Ltd., Tokyo, Japan) model SSD 500 with a $5 \mathrm{MHz}$ frequency transducer. Luteal tissue volume and cavity were calculated by the formula math: $\mathrm{V}=4 / 3 \mathrm{P} \cdot \mathrm{a} / 2$. (b/2) 2, where $\mathrm{a}=$ longitudinal axis and $\mathrm{b}=$ transverse axis (Spell et al., 2001). Blood samples were collected shortly after by venipuncture of coccygeal vessels with 21GX1 needles (Vacutainer® BD, São Paulo, SP, Brazil) and stored in heparinized vacuum blood collection tubes (Vacutainer® BD, São Paulo, SP, Brazil). The tubes were kept in refrigerated thermal boxes until centrifugation time at $2500 \mathrm{xg}$ for 15 minutes. The obtained plasma was sorted in identified plastic tubes and kept in a freezer at $80^{\circ} \mathrm{C}$ until hormone level evaluations. $\mathrm{P}_{4}$ plasma levels were determined by commercial solidphase kits (Coat-A-Count, Siemens Medical Solutions Diagnostics, Los Angeles, USA), by radioimmunoassay system (Packard Cobra II Auto Gamma, GMI Incorporation, Ramsey, USA). Samples were processed in two assays, with $1.87 \%$ intra-assay coefficient, $3.75 \%$ interassay coefficient and $0.02 \mathrm{ng} / \mathrm{mL}$ sensitivity.

Statistical analyzes of the evaluated characteristics were performed using the Statistical Analysis System (SAS, System for Windows, 2001). $\mathrm{P}_{4}$ plasma concentration and corpus luteum volume variables were compared at different times by the GLM procedure of SAS (General Linear Model Procedure PROC GLM) using the Student-Newman-Keuls (SNK) test.

Analyzes of variance and regression were performed to compare P4 plasma concentration between different groups with the sampling days as a source of variation. Student's t-tests were used to compare the means, with $95 \%$ significance level $(\mathrm{p}<0.05)$. The dependent variables were $\mathrm{P}_{4}$ plasma concentration and corpus luteum volume, while harvest days and cows were independent variables.

\section{RESULTS}

Experiment 1: Flunixin meglumine effect on bovine embryo recipient's pregnancy rate. From a total of 184 embryos anovulations, $148(80.4 \%)$ were classified with as score 1 of difficulty, 30 (16.3\%) were classified with score 2 and only 6 $(3.3 \%)$ anovulations were classified with score 3 . However, there was no difference $(p>0.05)$ in the pregnancy rate between the animals that were submitted to procedures classified with different scores of difficulty, furthermore, regarding body condition score, pregnancy rate was $43.92 \%$ $(65 / 148), 36.67 \%(11 / 30)$ and $33.33 \%(2 / 6)$ for animals with scores 1,2 and 3 respectively.

The overall pregnancy rate of 184 embryo recipients at the 30th day of gestation was $42.39 \%$ (78/184). There was no significant difference between pregnancy rate of the animals in group 1 $(40.22 \%$ - 37/92) in relation to group $2(44.57 \%$ 41/92) ( $\mathrm{p}=0.55)$. Similarly, there was no difference in pregnancy rates between different experimental groups considering the different stages of embryonic development (BI, BL and BX) ( $p>0.05)$. The results regarding the rates of pregnancy of embryo recipients used in experiment 1 are presented in table 1 . The total embryo/fetal loss rate between approximately 30 and 60 days of gestation was $3.85 \%$ (3/78), with no significant difference between groups and different stages of embryonic development (Table 2).

Table 1. Pregnancy rate at 30 days of gestation of recipients using in vitro produced embryos at different stages of development. Group $1=$ Control; Group $2=$ FM $1.1 \mathrm{mg} / \mathrm{kg}$ at the transfer time

\begin{tabular}{|c|c|c|c|c|}
\hline \multicolumn{5}{|c|}{ 30-day pregnancy rate $(\%)$} \\
\hline Groups & Initial Blastocyst & Blastocyst & $\begin{array}{l}\text { Expanded } \\
\text { Blastocyst }\end{array}$ & Total \\
\hline Group 1 & $40.0 \%(8 / 20)^{\mathrm{ab}}$ & $52.9 \%(18 / 34)^{\mathrm{a}}$ & $28.9 \%(11 / 38)^{\mathrm{b}}$ & $40.2 \%(37 / 92)$ \\
\hline Group 2 & $35.0 \%(7 / 20)^{\mathrm{c}}$ & $52.9 \%(18 / 34)^{\mathrm{c}}$ & $42.1 \%(16 / 38)^{\mathrm{c}}$ & $44.6 \%(41 / 92)$ \\
\hline Total & $37.5 \%(15 / 40)^{\mathrm{de}}$ & $52.9 \%(36 / 68)^{\mathrm{d}}$ & $35.5 \%(27 / 76)^{\mathrm{e}}$ & $42.4 \%(78 / 184)$ \\
\hline
\end{tabular}


Table 2. Rate of embryonic loss between approximately 30 and 60 days of gestation of recipients of in vitro produced bovine embryos at different stages of development. Group $1=$ control group; Group $2=$ group of recipients treated with flunixin $1.1 \mathrm{mg} / \mathrm{kg}$ meglumine at embryos innovation

\begin{tabular}{lcccc}
\hline \multicolumn{5}{c}{ Embryonic loss between approximately 30 and 60 days (\%) } \\
\hline Groups & $\begin{array}{l}\text { Initial Blastocyst } \\
\text { Glastocyst }\end{array}$ & $\begin{array}{l}\text { Expanded } \\
\text { Blastocyst }\end{array}$ & Total \\
Group 1 & $0.0 \%(0 / 8)^{\mathrm{a}}$ & $0.0 \%(0 / 18)^{\mathrm{a}}$ & $9.1 \%(1 / 11)^{\mathrm{a}}$ & $2.7 \%(1 / 37)$ \\
Group 2 & $14.3 \%(1 / 7)^{\mathrm{b}}$ & $5.6 \%(1 / 18)^{\mathrm{b}}$ & $0.0 \%(0 / 16)^{\mathrm{b}}$ & $4.9 \%(2 / 41)$ \\
Total & $6.7 \%(1 / 15)^{\mathrm{c}}$ & $2.8 \%(1 / 36)^{\mathrm{c}}$ & $3.7 \%(1 / 27)^{\mathrm{c}}$ & $3.9 \%(3 / 78)$ \\
\hline
\end{tabular}

$\mathrm{a}, \mathrm{b}, \mathrm{c}$ Values in the same row do not differ significantly $(\mathrm{p}>0.05)$

Experiment 2: Flunixin meglumine effect on luteal phase characteristics of bovine embryo recipients. After two applications of sodium cloprostenol with an 11-day interval between applications, 25 of 33 bovine females presented signs of estrus during the observation period, representing $75.76 \%$ of the total animals. Furthermore, from a total of 22 manipulations performed for positioning the embryo transfer gun in the final third of the uterine horn, $10(45.4 \%)$ were classified with score 1 difficulty, 8 (36.4\%) were classified with score 2 , and $4(18.2 \%)$ were classified with score 3.Control group animals (group 1) presented the highest mean value for $\mathrm{P}_{4}$ plasma concentrations on day 14 of the estrous cycle $(5.85 \mathrm{mg} / \mathrm{mL})$. During the interval between D7 and D14 there was a gradual increase in $\mathrm{P}_{4}$ mean values and from day 14 there was a daily decrease in $\mathrm{P}_{4}$ mean values (figure 1 and Table 3 ).

Table 3. Mean values for progesterone plasma concentrations (ng/mL) during the luteal phase (D7 to D18) of the animals in the different experimental groups (Group 1 - control animals; Group 2 - animals submitted to reproductive tract manipulation in D7; Group 3 - animals submitted to reproductive tract manipulation and treated with $1.1 \mathrm{mg} / \mathrm{kg}$ of flunixin meglumine in D7) (mean \pm standard error)

\begin{tabular}{lccc}
\hline \multicolumn{4}{c}{ Progesterone Plasma Concentrations (ng / mL) } \\
\hline Days & G1: Control $(\mathrm{n}=7)$ & $\begin{array}{c}\text { G2: Manipulation }(\mathrm{n}= \\
8)\end{array}$ & $\begin{array}{c}\text { G3: Manip. + FM }(\mathrm{n}= \\
7)\end{array}$ \\
\hline Day 7 & & & \\
Day 9 & $4.09 \pm 0.40^{\mathrm{a}}$ & $4.37 \pm 0.36^{\mathrm{a}}$ & $3.98 \pm 0.23^{\mathrm{a}}$ \\
Day 11 & $4.24 \pm 0.30^{\mathrm{b}}$ & $4.34 \pm 0.35^{\mathrm{b}}$ & $4.11 \pm 0.15^{\mathrm{b}}$ \\
Day 13 & $4.34 \pm 0.33^{\mathrm{c}}$ & $3.85 \pm 0.60^{\mathrm{c}}$ & $4.42 \pm 0.38^{\mathrm{c}}$ \\
Day 14 & $4.98 \pm 0.37^{\mathrm{d}}$ & $3.91 \pm 0.78^{\mathrm{e}}$ & $4.65 \pm 0.61^{\mathrm{d}}$ \\
Day 15 & $5.85 \pm 0.38^{\mathrm{f}}$ & $4.11 \pm 0.89^{\mathrm{g}}$ & $5.26 \pm 1.03^{\mathrm{f}}$ \\
Day 16 & $5.14 \pm 0.22^{\mathrm{h}}$ & $4.03 \pm 0.82^{\mathrm{i}}$ & $5.41 \pm 0.74^{\mathrm{h}}$ \\
Day 17 & $4.70 \pm 0.32^{\mathrm{j}}$ & $3.64 \pm 0.76^{\mathrm{k}}$ & $5.23 \pm 0.68^{\mathrm{j}}$ \\
Day 18 & $3.60 \pm 0.56^{\mathrm{l}}$ & $2.74 \pm 0.57^{\mathrm{m}}$ & $3.83 \pm 0.59^{1}$ \\
Day 19 & $1.81 \pm 0.50^{\mathrm{n}}$ & $1.61 \pm 0.38^{\mathrm{n}}$ & $2.12 \pm 0.41^{\mathrm{n}}$ \\
\hline
\end{tabular}

a, b, c, d, e, f, g, h, i, j, k, l, m, n, o Values with different superscripts in the same line differ significantly $(\mathrm{p}<0.05)$.

On the other hand, the mean value of group 3 (manipulation $+\mathrm{FM}) \mathrm{P}_{4}$ plasma concentrations did not differ from the value observed in the control group during the same period (G1) (p> $0.05)$. However, when compared to group 2 (manipulation), group 3 as well as control group (G1) also had higher $\mathrm{P}_{4}$ plasma concentrations during the same interval.

A difference $(\mathrm{p}<0.05)$ was observed in the mean values for $\mathrm{P}_{4}$ plasma concentrations from $\mathrm{D} 7$ until the end of the luteal phase (D19) when groups G1 and G3 were compared to G2 (tract manipulation), being the values higher for G1 and G3 group, ( $\mathrm{p}=$ 0.018, Figure 2).

\section{DISCUSSION}

Several studies have demonstrated the positive effects on pregnancy rates and maintenance of gestation to term through the utilization of 
prostaglandin synthesis inhibitors (Elli et al., 2001; Pugh et al., 2004; Scenna et al., 2005).

Although unmeasured in the current study, it is expected that there will be a slight PGF $2 \alpha$ release during embryo transfer, since the great majority of the procedures $(80.4 \%$ - 148/184) were classified as score 1 (easy cervix transposition and positioning of the device in the final third of the uterine horn requiring minimal manipulation), a fact probably due to the careful discard of recipients that previously had a difficult run through cervix at the transferring trial. Rowe et al. (1980) had already reported an inverse correlation between time and difficulty found to perform embryo transfer, with pregnancy rates of bovine embryo recipients. Similarly, Schrick et al. (2003) reported that as difficulty for embryo transfer increased, pregnancy rate decreased significantly.

Therefore, the low amounts of PGF $2 \alpha$ released by endometrium from control group recipients in the current study were probably not sufficient to affect embryonic development or even to exert some deleterious effect on corpus luteum functionality, thus, justifying the absence of difference between pregnancy rates in control and treated group. A probably possible factor that justifies this disagreement between results obtained in the above-mentioned studies and the present study is the difference in the amount of endometrium PGF $2 \alpha$ released at the moment of the embryo transfer procedure.

Another factor that may have influenced the lack of positive effect of FM administration on bovine pregnancy rate was the degree of embryos quality, being reported by Schrick et al. (2001), that the effect of FM on pregnancy rate depends on embryonic quality and its stage of development. In an interesting study (Scenna et al., 2005) in animals submitted to an FM application at the time of transfer, a significant increase in pregnancy rate on treated animals when compared to controls, in recipients that received fresh and frozen in vitro produced embryos classified with grade 1 quality was not observed. However, animals that received a grade 2 embryo and were submitted to an FM application had an $11 \%$ higher pregnancy rate than the control group. Similarly, Purcell et al. (2005) reported a beneficial effect of FM administration on pregnancy rates of recipients who received fresh and frozen in vivo produced embryos grade 2 and 3 qualities.
Therefore, the fact that only grade 1 quality embryos were used in the present study may be a factor that contributed to the lack of difference between pregnancy rates between the different experimental groups. Similar to the observed in this work, another study (Veloso Neto et al., 2014), that only used grade 1 embryos also did not obtain statistical differences in treatments between pregnancy rates or embryo loss reduction.

Furthermore, regarding the synchronization, Fernandes et al. (2006) obtained similar results in crossbred embryos recipients (82.9\% - 199/240) which underwent cloprostenol application between days 6 and 17 of the estrous cycle. Similarly, Ávila Pires et al. (2003) obtained estrous synchronizations varying between 70 and $85 \%$ after two cloprostenol applications with an interval of 11 to 14 days between applications in Zebu females. No difference was observed between corpora lutea means on the different groups throughout luteal phase ( $p>0.05$ ). However, around the seventh day (D7) to ninth day (D9) of the estrous cycle, the largest corpora lutea volume was observed in all experimental groups, and from that period a gradual decrease in their volume was observed during the rest of the phase luteal. Similar data were observed in other studies (Viana et al., 2000; Acosta et al., 2003; Borges et al., 2003).

Studies have evaluated the effect of reproductive tract manipulation on PGF $2 \alpha$ release in cows, either through concentration of prostaglandin metabolites (Wann \& Randel, 1990), or direct PGF2 $\alpha$ evaluation through saphenous vein cannulation (Scenna et al., 2005). In both studies it was identified that manipulation results in PGF $2 \alpha$ release by the endometrium. In addition, Scenna et al. (2005) identified a pulsatile pattern of PGF $2 \alpha$ release after manipulation, much like PGF $2 \alpha$ release pattern at the time of luteolysis.

Therefore, although it was not quantified in the present study, it is probable that there was a significant PGF $2 \alpha$ release by the endometrium of the animals that underwent reproductive tract manipulation in experiment 2. Some factors support this hypothesis, such as: high incidence of embryo transfer procedures that were classified with score 2 and 3 of difficulty (medium difficulty and high difficulty, respectively, 54.6\% - 12/22) and the lack of previous selection of the animals 
in relation to cervix and uterus anatomy since these females had never undergone a previous transfer.

Interestingly, several factors suggest that there was a more pronounced PGF $2 \alpha$ release by the endometrium of animals submitted to reproductive tract manipulation in experiment 2 when compared to experiment 1. Schramm et al. (1983) evaluated the effect of PGF $2 \alpha$ administration on different frequencies and concentrations on corpus luteum functionality in sheep. In accordance, the authors observed that at least 5 PGF $2 \alpha$ pulses were required over a period of 25 hours for occurrence of permanent luteolysis in most animals, however, when assessing the effect of only one daily PGF $2 \alpha$ pulse on corpus luteum, functionality was observed.

Furthermore, another similarity between the studies is that there was a significant decrease in $\mathrm{P}_{4}$ secretion rate, which was later followed by recovery in $\mathrm{P}_{4}$ secretion profile. It is probable that uterine manipulation performed in group 2 females triggered PGF2 $\alpha$ release by the endometrium, which, in turn, led to a temporary reduction in the capability of the corpus luteum to secrete $\mathrm{P}_{4}$ in 3 animals (37.5\%), and stimulated an early CL regression in one animal $(12.5 \%$,). Interestingly, FM administration was apparently effective in blocking PGF2 $\alpha$ synthesis by endometrium in 5 females caused by reproductive tract manipulation, however, two females showed P4 plasma concentration decrease after manipulation, indicating that for some specific reason FM administration was not effective in blocking PGF2 $\alpha$ synthesis in these animals.

\section{CONCLUSIONS}

This study demonstrated that manipulation of the reproductive tract of cows at the time of embryo transfer did not alter the duration of the luteal phase, however, it decreased $\mathrm{P}_{4}$ plasma concentrations of these animals. Furthermore, although FM administration at the time of the procedure was effective in inhibiting the decrease $\mathrm{P}_{4}$ plasma concentrations, it did not increase the pregnancy rate of recipients.

\section{ACKNOWLEDGEMENTS}

To Coordination of Improvement of Higher Education Personnel (CAPES) for the scholarship granted. To Chemitec Agro-Veterinária for medicine supply and Biotran Ltda for assistance in carrying out practical activities.

\section{REFERENCES}

ACOSTA, T.J.; HAYASHI, K.G., OHTANI. et al. Local changes in blood flow within the preovulatory follicle wall and early corpus luteum in cows. Reproduction, v.125, p.759-767, 2003.

ÁVILA PIRES, M.F.; ALVES, N.G.; SILVA FILHO, J.M. et al. Comportamento de vacas raça Gir (Bos taurus indicus) em estro. Arq. Bras. Med. Vet. Zootec,. v.55, p.187-196, 2003.

BORGES, A.M.; TORRE, C.A.A.; RUAS, J.R.M. et al. Características da dinâmica folicular e regressão luteal de vacas das raças Gir e Nelore após tratamento com cloprostenol sódico. Rev. Bras. Zootec., v.32, p.85-92, 2003.

DZIUK, P.J., BELLOWS, R.A. Management of reproduction of beef cattle, sheep and pigs. $J$. Anim. Sci., v.57, p.355-379, 1983.

ELLI, M.; GAFFURI, B.; FRIGERIO, A. et al. Effect of a single dose of ibuprofen lysinate before embryo transfer on pregnancy rates in cows. Reproduction, v.121, p.151-154, 2001.

FERNANDES, C.A.C.; FIGUEIREDO, A.C.S.; OLIVEIRA, E.R. et al. Eficiência de detecção de estros em receptoras de embrião sincronizadas com cloprostenol. Acta Sci. Vet., v.34, p.494, 2006.

HOCKETT, M.E.; ROHRBACH, N.R.; SCHRICK, F.N. Alterations in embryo development in progestogen-supplemented cows administered prostaglandin F2 $\alpha$. Prostaglandins Other Lipid Mediat., v.73, p.227-236, 2004.

NARVÁEZ, H.J.; FONTES, R.S.; COSTA, R.L.D. et al. Efeito do ibuprofeno administrado uma hora antes da inovulação de embriões bovinos. Arq. Bras. Med. Vet., v.62, p.504-510, 2010. 
PUGH, M.L.; MOREIRA, M.B.; GILBERT, G.R. et al. Influence of prostaglandin F2 synthesis inhibitors on pregnancy rate of embryo transfer recipients heifers. In: INTERNATIONAL CONGRESS ON ANIMAL REPRODUCTION, 15., 2004, Porto Seguro. Anais... Porto Seguro: [s.n.], 2004.p.399.

PURCELL, S.H.; BEAL, W.E.; GRAY, K.R. Effect of a CIDR insert and flunixin meglumine, administered at the time of embryo transfer on pregnancy rate and resynchronization of estrus in beef cattle. Theriogenology, v.64, p.867-878, 2005.

RIBEIRO FILHO, A.L.; FREITAS, D.S.; RODRIGUES, A.S. et al. Uso de um inibidor da síntese de prostaglandinas em receptoras bovinas com ou sem dificuldade de transposição cervical. Rev. Bras. Saúde Prod. Anim., v.12, p.819-827, 2011.

ROWE, R.F.; DEL CAMPO, M.R.; CRISTER, J.K. Embryo transfer in cattle: non-surgical transfer. Am. J. Vet. Res., v.41, p.1024-1028, 1980.

SCENNA, F.N.; HOCKETT, M.E.; TOWNS, T.M. et al. Influence of a prostaglandin synthesis inhibitor administered at embryo transfer on pregnancy rates of recipient cows. Prostaglandins Other Lipid Mediat. v.8, p.38-45, 2005.

SCHALLENBERGER, E.; SCHAMS, D.; MEYER, H.H.D. Sequences of pituitary, ovarian, and uterine hormone secretion during the first 5 weeks of pregnancy in dairy cattle. J. Reprod. Fertil., v.37, p.277-286, 1989.

SCHRAMM, W.; BOVAIRD, L.; GLEW, M.E. et al. Corpus luteum regression induced by ultra-low pulses of prostaglandin F2 alpha. Prostaglandins, v.26, p.347-364, 1983.
SCHRICK, F.N.; HOCKETT, M.E.; TOWS, T.M. et al. Administration of a prostaglandin inhibitor immediately prior to embryo transfer improves pregnancy rates in cattle. Theriogenology, v.5, p.370, 2001.

SCHRICK, F.N.; SCENNA, F.N.; EDWARDS, J.L. et al. More evidence for a direct interaction between prostaglandin F $2 \alpha$ and development of bovine embryos. In: CANADIAN EMBRYO TRANSFER ASSOCIATION AND AMERICAN EMBRYO TRANSFER ASSOCIATION JOINT ANNUAL CONFERENCE, 2003. Proceedings... [s.1.]: [s.n.], 2003. p.43-52.

SPELL, A.R.; BEAL, W.E.; CORAH, L.R. et al. Evaluating recipient and embryo factors that affect pregnancy rates of embryo transfer in beef cattle. Theriogenology, v.56, p.287-297, 2001.

VELOSO NETO, H.F.; SILVA, J.C.F.; SALES, F.A.B.M. et al. Efeito do flunixin meglumine e da somatotropina recombinante bovina sobre a taxa de prenhez de receptoras bovinas de embriões fecundados in vitro. Med. Vet., v.8, p.11-16, 2014.

VIANA, J.H.M.; FERREIRA, A.M.; SÁ W.F. Follicular dynamics in Zebu cattle. Pesqui. Agropecu. Bras., v.35, p.2501-2509, 2000.

WANN, R.A.; RANDEL, R.D. Effect of uterine manipulation 35 days after parturition on plasma concentrations of 13, 14-dihydro-15-keto prostaglandin $\mathrm{F} 2 \mathrm{a}$ in multiparous and primiparous Brahman cows. J. Anim. Sci., v.68, p.1389-1394, 1990.

WILTBANK, M.C.; GUTHRIE, P.B.; MATTSON, M.P. et al. Hormonal regulation of the free intracellular calcium concentrations in small and large ovine luteal cells. Biol. Reprod., v.41, p.771-777, 1989.

YOUNG, L.E.; SINCLAIR, K.D.; WILMUT, I. Large offspring syndrome in cattle and sheep. Rev. Reprod., v.3, p.155-163, 1998. 